\title{
Size and genotype affect resistance to mortality caused by OsHV-1 in Crassostrea gigas
}

\author{
Lionel Dégremont'*
}

Ifremer, SG2M, LGP2M, Avenue Mus de Loup, 17390 La Tremblade, France

*: Corresponding author : Lionel Dégremont, tel.: + 33546762630 ; fax: + 33546762611 ; email address : lionel.degremont@ifremer.fr

\begin{abstract}
:
As with summer mortalities reported in France between 2001 and 2006, mortality caused by the Ostreid herpesvirus 1 (OsHV-1) in Crassostrea gigas affects mostly juveniles, although adults can also be impacted to a small extent. This could suggest that both mortalities have similar causes and that establishment of resistance, in particular to the Ostreid herpesvirus 1 (OsHV-1), depends on either the size or the age of oysters. The present study reports an investigation of both size and age using three cohorts produced during winter and three produced during summer. Each cohort contained oysters genetically selected to be resistant or susceptible to the summer mortality phenomenon, as well as unselected control oysters. Any abnormal mortality was recorded between production and placement in the field. Transfer to field conditions was then made over thirty deployments between July 2009 and September 2011. All mortalities occurred when seawater temperature was above $16^{\circ} \mathrm{C}$, which was termed the 'risk' period. For all deployments made during the risk period, mortality was observed within two weeks post-deployment and most episodes lasted over a week. For deployments made outside of the risk period, mortality occurred as soon as the next risk period began. The absence of detection of OsHV-1 at deployment, the presence of a high viral load of OsHV-1 (> $10^{+6}$ DNA copies per mg of fresh tissue) on moribund oysters sampled during peak mortality, and the mortality kinetic all suggest that the mortalities can be attributed to this pathogen alone. The major finding of this study was that the resistance to mortality caused by OsHV-1 increased with both age and size, suggesting a maturation of the immune system against the virus. In field conditions, the relationship between mortality and size was stronger than the relationship between mortality and age. Regression equations of oyster size or age at the onset of the mortality event were derived to estimate the mortality due to OsHV-1. Although larger animals always tended to be more resistant to OsHV-1 than smaller ones, mortality in unselected oysters remained high $(>70 \%)$ for the size range $0-10 \mathrm{~g}$. Selective breeding to improve resistance to OsHV-1 remains the best way to significantly reduce mortality; however, prudent management strategies for oyster growers could also potentially offer viable solutions. For example, deploying juveniles at a site favouring the growth of oysters after the threat of exposure to OsHV-1 has passed (i.e. at the end of the risk period), and by using cultural practices favouring high growth and/or a site for which the risk period is short due to the seawater temperature. Use of triploid oysters or lines selected for higher growth is also discussed.
\end{abstract}

\section{Highlights}

Oyster mortality was always observed when seawater temperature was above $16{ }^{\circ} \mathrm{C} \rightarrow$ Mortality kinetics and high OsHV-1 load implicate this virus in the mortality Oyster size had a greater influence on mortality than oyster age Larger and older animals can develop resistance to OsHV-1 Management strategies for oyster growers would help to minimize mortality.

Keywords: Mortality ; Crassostrea gigas ; Disease resistance ; Size ; Age ; Ostreid herpesvirus 


\section{Introduction}

Summer mortality in Crassostrea gigas has been reported throughout the world, in Japan in 1915 (Takeuchi et al., 1960; Koganezawa, 1975), the USA in the late 1950s (Glude, 1975), France during the 1980s (Maurer et al., 1986) and more recently in Germany (Daehne et al., 2009), Ireland (Malham et al., 2009) and Wales (Cotter et al., 2010). The role of pathogens was not clear until the investigation of the more severe mortality outbreaks occurring in France since 2008, in which the Ostreid herpesvirus 1 (OsHV-1) was frequently detected (Segarra et al., 2010). Similar mortalities also occurred in other countries of Europe, in Australia and New Zealand, and on the west coasts of the USA at this time (The Fisheries Research and Development Corporation, 2011; Burge and Friedman, 2012; Lynch et al., 2012; Martenot et al., 2012; Peeler et al., 2012; Roque et al., 2012).

Breeding investigations revealed high genetic basis for survival during summer mortality events in juvenile Crassostrea gigas and a positive response to selection to improve or decrease survival (Dégremont et al., 2007, 2010b). Oysters lines bred from families selected in 2001 to be either resistant or susceptible to summer mortality, hereafter referred to as $R$ and $\mathrm{S}$, respectively, still exhibit contrasted survival in the context of the more severe mortality outbreaks occurring in France since 2008 (Dégremont, 2011). It was also shown that $R$ oysters were capable of limiting the infection by OsHV-1 in comparison to $\mathrm{S}$ and unselected oysters, indicating their resistance to the disease and supporting the hypothesis that summer mortality and the particularly severe mortality outbreaks observed in juvenile $C$. gigas since 2008 in France probably result from the same phenomenon (Dégremont, 2011).

Indeed, the first disease investigation clearly showed relationship between OsHV-1 detection and C. gigas spat mortality in France between 1998 and 2006 (Garcia et al., 2011). The detection of OsHV-1 in moribund oysters during mortality events in laboratory trials and in nursery were also reported in 1995 (Renault et al., 1995) and from 2001 to 2003, as were strong correlations between laboratory and field mortality (Dégremont, 2003; Dégremont et al., 2010a). OsHV-1 was also detected in three full-sib families of the R and S lines in 2006, and QTL for resistance to summer mortality and OsHV-1 load were then found using these lines (Sauvage et al., 2009, 2010). Additionally, the kinetics of the mortality in laboratory trials in 2002 and 2003 were similar to those found in the field in 2009 , with $90 \%$ of the cumulative mortality occurring within a week (Dégremont et al., 2010a; Dégremont, 2011).

Disease investigation showed higher susceptibility to OsHV-1 in juveniles than adults (Renault and Novoa, 2004), and genetic investigation showed similar results with juvenile oysters being more susceptible to summer mortality than adults (Dégremont et al., 2010c). This last result revealed the importance of the age and/or size for the establishment of the resistance during the oyster development; however, several questions remain unanswered. For example, at what age do $\mathrm{R}$ and $\mathrm{S}$ oysters show contrasted survival? Is the difference present from hatching or does appear in at a later stage of development? How does phenotypic variance evolve through the development of $C$. gigas? Which is the key factor for OsHV-1-related mortality: age or size? Using the lines selected for contrasted survival/resistance and unselected controls, this study aimed to address these questions through an investigation of size and age at the juvenile stage in field conditions. 


\section{Materials and methods}

\subsection{Biological materials}

To distinguish the relative influence of age and/or size on mortality, several cohorts were produced either during winter or summer and deployed several times in order to provide as large a range of ages and sizes as possible, and also to expose oysters from the same genetic groups with similar sizes but different ages to the same OsHV-1-related mortality risks.

From 2009 to 2011, one cohort per year was produced during the winter, each consisting of three groups (selected R, selected $S$, and unselected, hereafter referred to as ' $C$ ') within which there were two replicate batches each. Additionally, three cohorts were produced during the summer, one in 2009 and two in 2010, and the number of batches per group is indicated in Table 1. Additional batches were also produced from the summer spawnings, but were not allocated to the above groups as they were issued from crosses between $C$ and $\mathrm{R}$ oysters and were either diploid or triploid. These additional oysters were grown alongside the experimental oysters to observe the trend of mean mortality according to their age and/or size. Unselected oysters were sampled from a wild population in Marennes-Oléron Bay in 2009 and 2010. For each cross, an average of 36 parents was used. Larval rearing and settlement stages took place at the Ifremer hatchery in La Tremblade. The spat were then transferred and maintained at the Ifremer nursery in Bouin until field deployment. Any abnormal mortality was recorded from the spawn to the field deployment. Further details on these steps and on selection criterion are given in Dégremont et al. (2005, 2007, 2010a, $2010 \mathrm{~b}$ ). The $R$ oysters of cohorts 3 and 4 were produced using survivors of the $R$ batches tested in cohort 1; likewise, the $\mathrm{R}$ oysters of cohorts 5 and 6 were produced using the survivors of cohort 3 . This meant that the later cohorts had one or two more rounds of mass selection for survival in comparison with the R batches of cohorts 1 to 2 .

\subsection{Field study}

All oysters were all tested at Agnas in Marennes-Oléron Bay $\left(45^{\circ} 52^{\prime 2} 3^{\prime \prime} \mathrm{N}, 1^{\circ} 10^{\prime} 15^{\prime \prime} \mathrm{W}\right)$ using bags attached to racks. For each cohort, several deployments from nursery to field were made at monthly intervals, as detailed in Table 1. For example, oysters of cohort 1 were deployed in the field from July to October 2009, while those of cohort 2 were deployed from March to September 2010. At each deployment, the progenies were represented by two bags of 150 oysters each and the total weight of the oysters was recorded. Oysters were checked two weeks post-deployment, and mortality and total weight of the live oysters were recorded two weeks post-mortality for the spring deployments, and one month after the mortality peak. The seawater temperature was recorded throughout the study using an YSI probe \#6600.

\subsection{OsHV-1 detection and quantification}

Live oysters were sampled for some batches of cohorts 1,2 and 3 at the IFREMER nursery before deployment in the field, representing a total of 408 oysters (Table 1). Moribund oysters were also sampled during the period of peak mortality each year $(n=72$ oysters, Table 1). Oysters were individually diagnosed for OsHV-1 using the real-time PCR technique developed by Pépin et al. (2008) and the protocol described in Sauvage et al. (2009). 


\subsection{Statistical analyses}

Mortality was analysed within cohort using the GENMOD procedure SAS $®$ software version 9 with a probit transformation and a binomial distribution:

Probit $(\mathrm{Y} i)=\mu+$ date of field deployment $i$,

where $\mathrm{Y} i$ is the probability of the mortality for the ith deployment and $\mu$ is the intercept. Multiple comparison tests were conducted using the least squares means statement and the pdiff option (Littell et al., 2002).

For the analysis of the effect of age on mortality onset, only $R, S$ and $C$ batches were included in the statistical analyses. The CORR procedure was used to calculate the Pearson correlations between the probit transformation of the mortality and the age when mortality started, and between the mortality parameter and the mean individual weight. This weight was estimated by dividing the total weight by the number of live oysters. It was measured either at deployment if mortality was within the first two weeks post-deployment, or two weeks post-mortality when mortality occurred latter.

Finally, the estimated regression equations were obtained for the $\mathrm{R}, \mathrm{S}$ and $\mathrm{C}$ groups in order to compute the predicted mortality for a desired size (in $\mathrm{g}$ ) or age (in months) of a C. gigas oyster subjected to OsHV-1 for the first time.

\section{Results and Discussion}

According to the experimental design of this study, it was not possible to test within batch and deployment if mortality was different among sizes by measuring the dying and the surviving oysters during the mortality peaks. Thus, any data is available on the mortality pattern for the entire size class within batch and deployment, which could be the results of complex interaction between growth, size, genotype, environment and a low effective size, as survival is a is highly heritable trait for juvenile C. gigas (Dégremont et al., 2010b). Meanwhile, the main objective of this study was to investigate the mortality of oysters for a broad range of age (3-20 months old) and size (1 to $25 \mathrm{~g}$ ) in a disease-contaminated site, where heavy mortality associated to OsHV-1 is routinely observed since 2009 .

Seawater temperature at Agnas ranged from 4 to $23^{\circ} \mathrm{C}$ between July 2009 and July 2012, as shown on Fig.1. All mortality episodes started within the first two weeks post-deployment for deployment made from June to September, while mortality started in May or June for the deployments made in autumn and spring (Table 1). Additionally, two mortality events were observed for the last deployment of the cohort 5 , one within the first two weeks postdeployment and the second in the following spring (Table 1 and Fig. 2a). It should be noted that all mortality events occurred when seawater temperature was above $16^{\circ} \mathrm{C}$ (Fig. 2a), which confirms the new lower threshold defined in the Thau lagoon around $17^{\circ} \mathrm{C}$ (Pernet et al., 2012) and in cohabitation trials in the laboratory using an unheated seawater flowthrough system (Dégremont et al., 2013).

For all deployments, $80 \%$ of the cumulative mortality occurred within a week following the onset of mortality. The kinetic of mortality for all deployments, whatever the cohorts, confirmed the short-term nature of the phenomenon, in agreement with previous studies on summer mortality in C. gigas in France between 2001 and 2004 (Dégremont et al., 2010a), as well as the recurrent mortality events reported in France since 2008 (Dégremont, 2011; Pernet et al., 2012). Furthermore, the latter studies showed the involvement of OsHV-1, and experimental infection by OsHV-1 through injection or cohabitation also showed similar kinetics (Schikorsky et al., 2011a, 2011b). In the present study, OsHV-1 was not detected in 
any of the 408 oysters tested before their deployment in the field. Conversely, all moribund oysters were found positive for OsHV-1. Their viral load was high, exceeding $10^{+6}$ DNA copies per mg of fresh oyster tissue, which corresponds to lytic infection associated with very high-level replication, when virus particles burst or lyse host cells. Additionally, OsHV-1 is considered to be the main cause of mortality in $C$. gigas when viral load exceeds $10^{+5}$ DNA copies per mg (Dégremont, 2011; Dégremont et al., 2013, Oden et al., 2011; Pépin et al., 2008; Sauvage et al., 2009; Schikorsky et al., 2011a, 2011b). Altogether, the absence of detection of OsHV-1 at deployment, the onset of the mortality at temperatures above $16^{\circ} \mathrm{C}$, the kinetics of the mortality, and the high viral load on moribund oysters strongly suggest that mortalities occurring during this study can be attributed to this pathogen alone. Finally, to strengthen this conclusion, a more detailed disease screening, made on the same groups at the time of the third deployment of the first cohort, showed a high and strong correlation between mortality and OsHV-1, while no such relation was found between mortality and Vibrio splendidus, and V. aestuarianus was not detected in this study (Dégremont, 2011).

Significant differences in mortality among deployments were observed for cohorts 1,2 and 3 $(0.0001<P<0.044)$ with the highest mortality for the first deployments and the lowest for the last deployment (Table 1). For the cohorts 4,5 and 6 , no difference in mortality was found according to date of deployment $(P>0.49)$, but mortality of cohort 5 decreased from $67-70 \%$ for the first deployments to $25 \%$ for the last (Table 1 ). The results clearly showed that older oysters are less sensitive to the mortality than younger ones, especially those from the $C$ and $S$ groups (Table 1), which underlines earlier findings on the summer mortality phenomenon (Dégremont et al., 2010c), and/or that larger oysters are less sensitive than smaller (Table 1, Fig. 2b). This also reinforced that summer mortality in juveniles before 2008 and recurrent mortality outbreaks caused by OsHV-1 observed in France since 2008 could be the same phenomenon.

Kinetics of the mortality and its period of occurrence for the largest oysters (> 12 months old and $15 \mathrm{~g}$ ), as well as the detection of OshV-1 for the cohort 1 on June 2010 showed that large oysters could also be affected by the disease, which is in agreement with results found by Pernet et al. (2012) and Dégremont et al. (2013). Interestingly, the mortality of adults was lower than juveniles, indicating that establishment of resistance to this pathogen either depends on size or age. In contrast, mortality in larger adults was not investigated in our study because it was not possible to preserve our experimental batches from the mortality risk factors during several years, and that any oyster farmer would do such cultural practice as most the oysters reach commercial size at 2 or 3 years old. Although it is not likely that development of resistance to OsHV-1 would change at older stage, further investigations would be necessary to investigate its role in older/larger adult, as well as for other causes of mortality.

Individual weights and ages, at deployment and mortality, are shown in Fig. 2b and Fig. 2c, respectively. The winter cohorts were similar in size at 3-6 months old to the summer cohorts at 9-12 months old, as the latter did not grow much during the over-wintering period. As the groups showed similar mortality, this indicates that it is size, rather than age, that corresponds to a particular physiology. The inverse situation (same age different physiology) can arise in early life because $C$. gigas larvae can settle from day 12 to day 40 according to the seawater temperature and food supply. A month post-fertilization, therefore, progeny of the same spawning can be either spat or larvae at the same age. In this case they will have not only vastly different physiology but a different size, as a larva will always be smaller than a spat. As a consequence of oysters showing the same physiology at different ages in the present study, two age clusters appeared at high mortality levels $(>80 \%)$ for both the S and C groups at the onset of mortality (Fig. 3a). One cluster was 3-6 months old, corresponding to the winter cohorts and one was 9-12 months-old, corresponding to the summer cohorts. When individual weight is used, only one cluster was observed with high mortality $(>80 \%)$ (Fig. 3b). High and significant negative correlations were found between the mortality and 
oyster size in the S and C groups, $-0.88(n=36)$ and $-0.86(n=43)$, respectively, and to a lesser extent for the $\mathrm{R}$ group $(-0.48 ; n=36)$ (Table 2$)$. Correlations between mortality and age of the oysters were also significant and negative, but the relation was weaker than between mortality and size for the $C$ and $S$ groups (Table 2). The regression equations predicting mortality on the probit scale for a given size (here the individual weight in g) or age (in months) are indicated in Table 2. Thus, even if age and size are closely related, as older oysters will be larger in size than younger ones from the design of this study overall. The closer relationship between mortality and size than between mortality and age indicates that size of a $C$. gigas oyster is a more important parameter affecting the intensity of mortality due to OsHV-1 and could play a key role. Three other studies support this hypothesis. The first one reported summer seed mortality of $C$. gigas at Inner Tomales Bay in 2001, for which OsHV-1 was suspected as a possible cause. In this study, oysters were planted either in the autumn or the following spring, and autumn cohorts outperformed those planted in the spring because they were of much larger size at the time of the mortality event (Burge et al., 2007). Similarly, stocks consisting of smaller oysters had higher mortality related to OsHV-1 than those with larger ones in Tomales Bay in 2003 (Burge et al., 2006). Additionally, oyster cohorts planted during the summer in Thau lagoon in 2010 showed earlier and lower mortality than members of the same cohorts deployed later (Pernet et al., 2012). This indicated that older oysters had higher mortality than younger ones, but because the older oysters were smaller than the younger ones, these results support the hypothesis that mortality is more a question of size than of age. Additionally, most of the mortality rates observed in these earlier studies were close to the mortality estimated from the regression equations for the $C$ group in the present study (Table 3 ), but this similarity needs to be considered with caution as mortality due to OsHV-1 is environmentally-dependent (Garcia et al., 2011).

Size therefore represents another way, besides selection, to reduce OsHV-1-related mortality. Naïve $C$. gigas would be fare better against this source of mortality if they were larger when the seawater temperature approached $16^{\circ} \mathrm{C}$. While the highest mortality due to OsHV-1 would result from deploying the oysters at small size $(<10 \mathrm{~g})$ during the risk period, the transfer of juvenile $C$. gigas just after the risk period would minimize the mortality due to OsHV-1, as already suggested in Dégremont et al. (2010c). Furthermore, mortality should also be decreased by a few percent if the growing site was characterized by fast growth, seawater temperature reached $16^{\circ} \mathrm{C}$ as late as possible and cultural practices were used that favoured high growth (i.e., no emersion). Another way to obtain larger oysters would be to select oysters for faster growth, as done in C. virginica for resistance to Roseovarius crassostreae (Barber et al., 1996, 1998; Boettcher et al., 2005; Majoy et al., 2007). Similarly, triploid oysters could also have a small advantage over diploid ones due to their higher growth. However, the gain in survival from the use of triploids or oysters selected for growth would be limited due to the small amount of time available to grow the oysters before the risky period. Nevertheless, the use of OsHV-1-resistant oysters remains a good way to reduce mortality significantly (Dégremont et al., 2007, 2010b, 2011), with much lower mortality in the $R$ group than in the $C$ and $S$ groups (Table 1, Fig. 3ab).

This study showed higher mortality at lower size, indicating that selection, and its intensity, should be more efficient when testing oysters at small size (Fig. 3b). Differences in mortality between $\mathrm{R}$ and $\mathrm{C}$ oysters were observed in oysters weighing lesser than $1 \mathrm{~g}$ and then decreased for larger oysters (Fig. 3b). Nonetheless, further investigations are needed in order to test the resistance of the $\mathrm{R}$ oysters at earlier stages, (i.e., D-larvae, veliger larvae, pediveliger larvae and post-larvae), which could be easily done under laboratory conditions. Meanwhile, because the larger size of unselected oysters was correlated with lower mortality and higher resistance to OsHV-1, this suggests an underlying mechanism related to the immune system of $C$. gigas, taking place during the life of the animal, although no study has yet addressed this hypothesis. $R$ oysters should be capable of developing defence 
mechanisms earlier than unselected oysters and this remains to be investigated at earlier stages.

Finally, mortality of the $C$ groups was close to that of the S groups from 2009 to 2011 , which contrasted with mortality observed between 2001 and 2003, in which mortality of the controls groups was lower than mortality of the $S$ groups (Dégremont et al., 2010a, 2010b). The first hypothesis for this difference is a higher virulence of the OsHV-1 genotype $\mu$ var, which was first observed in 2008 (Segarra et al., 2010), but no studies have yet investigated the OsHV1 virulence between genotypes. The second hypothesis is that there now is a higher prevalence of the disease in cultured and/or wild stocks of $C$. gigas, but once again, lack of data does not allow this to be verified. The third hypothesis that there is a lower threshold of the seawater temperature before OsHV-1-related mortality is observed: this was around $19^{\circ} \mathrm{C}$ in the case of summer mortality between 2001 and 2005 (Ropert et al., 2007). This would lead to longer risk period or appearance of a risk period in sites where the temperature was usually lower than $19^{\circ} \mathrm{C}$. Finally, some combination of the three hypothesises could be responsible.

In conclusion, this study showed that the establishment of the resistance to mortality episodes caused by OsHV-1 was more closely related to the size than to the age of $C$. gigas in field conditions. For unselected oysters, larger animals were more resistant to OsHV-1 than smaller ones, and mortality remained high $(>70 \%)$ for sizes ranging from 0 to $10 \mathrm{~g}$. Regression analysis of oyster size at the onset of a mortality event was used to predict mortality due to OsHV-1 for sizes ranging from 0.16 to $30 \mathrm{~g}$. Selective breeding to improve resistance to OsHV-1 remains the best way to significantly reduce mortality; however, prudent oyster management strategies for growers include deploying juveniles after the threat of exposure to OsHV-1 has past, as suggested in Dégremont et al. (2010c), and utilizing a site and cultural practices that favour rapid growth.

\section{Acknowledgements}

I wish to thank the hatchery, nursery and genetic teams of the Laboratory Genetics and Pathology, IFREMER La Tremblade and IFREMER Bouin for their assistance in oyster production, as well as Jean Luc Seugnet for his help in field operations. I also acknowledge Florence Rivet for her help with bibliographic research and the Laboratory Environment and Resources of the Pertuis Charentais, IFREMER La Tremblade, for the temperature dataset. Finally, I thank J. David Lange and Dr. Helen McCombie for their help with the English in this manuscript.

\section{References}

Barber, B.J., Davis, C.V., Crosby, M.A., 1998. Cultured oysters, Crassostrea virginica, genetically selected for fast growth in the Damariscotta River, Maine, are resistant to mortality caused by Juvenile Oyster Disease (JOD). Journal of Shellfish Research 17, 1171-1175.

Barber, B.J., Carnegie, R.B., Davis, C.V., Mook, W., 1996. Effect of timing of seed deployment on growth and mortality of oysters, Crassostrea virginica, affected by Juvenile Oyster Disease (JOD). Journal of the World Aquaculture Society 27, 443448.

Boettcher, K.J., Geaghan, K.K., Maloy, A.P., Barber, B.J., 2005. Roseovarius crassostreae sp nov., a member of the Roseobacter clade and the apparent cause of juvenile oyster disease (JOD) in cultured Eastern oysters. International Journal of Systematic and Evolutionary Microbiology 55, 1531-1537. 
Burge, C.A., Friedman, C.S., 2012. Quantifying Ostreid Herpesvirus (OsHV-1) Genome Copies and Expression during Transmission. Microbial Ecology 63, 596-604.

Burge, C.A., Griffin, F.J., Friedman, C.S., 2006. Mortality and herpesvirus infections of the Pacific oyster Crassostrea gigas in Tomales Bay, California, USA. Diseases of Aquatic Organisms 72, 31-43.

Burge, C.A., Judah, L.R., Conquest, L.L., Griffin, F.J., Cheney, D.P., Suhrbier, A., Vadopalas, B., Olin, P.G., Renault, T., Friedman, C.S., 2007. Summer seed mortality of the Pacific oyster, Crassostrea gigas Thunberg grown in Tomales Bay, California, USA: The influence of oyster stock, planting time, pathogens, and environmental stressors. Journal of Shellfish Research 26, 163-172.

Cotter, E., Malham, S.K., O'Keeffe, S., Lynch, S.A., Latchford, J.W., King, J.W., Beaumont, A.R., Culloty, S.C., 2010. Summer mortality of the Pacific oyster, Crassostrea gigas, in the Irish Sea: The influence of growth, biochemistry and gametogenesis. Aquaculture 303, 8-21.

Daehne, B., Zabel, A., Meemken, M., Watermann, B.T., 2009. Mortality of the Pacific Oyster (Crassostrea gigas, Thunberg, 1793) in 2006 at the East Frisian coast, Germany, North Sea. Bulletin of the European Association of Fish Pathologists 29, 118-122.

Dégremont, L., 2003. Etude des bases génétiques de la mortalité estivale et des relations avec la croissance chez les juvéniles de Crassostrea gigas. Université de Caen Basse Normandie, Caen, pp. 333.

Dégremont, L., Bédier, E., Soletchnik, P., Ropert, M., Huvet, A., Moal, J., Samain, J.F., Boudry, P., 2005. Relative importance of family, site, and field placement timing on survival, growth, and yield of hatchery-produced Pacific oyster spat (Crassostrea gigas). Aquaculture 249, 213-229.

Dégremont, L., Ernande, B., Bédier, E., Boudry, P., 2007. Summer mortality of hatcheryproduced Pacific oyster spat (Crassostrea gigas). I. Estimation of genetic parameters for survival and growth. Aquaculture 262, 41-53.

Dégremont, L., Guyader, T., Tourbiez, D., Pépin, JF., 2013. Is horizontal transmission of the Ostreid herpesvirus OsHV-1 in Crassostrea gigas affected by unselected or selected survival status in adults to juveniles? Aquaculture 408-409, 51-57.

Dégremont, L., Soletchnik, P., Boudry, P., 2010a. Summer mortality of selected juvenile Pacific oyster Crassostrea gigas under laboratory conditions and in comparison with field performance. Journal of Shellfish Research 29, 847-856.

Dégremont, L., Bédier, E., Boudry, P., 2010b. Summer mortality of hatchery-produced Pacific oyster spat (Crassostrea gigas). II. Response to selection for survival and its influence on growth and yield. Aquaculture 299, 21-29.

Dégremont, L., Boudry, P., Ropert, M., Samain, J.-F., Bédier, E., Soletchnik, P., 2010c. Effects of age and environment on survival of summer mortality by two selected groups of the Pacific oyster Crassostrea gigas. Aquaculture 299, 44-50.

Dégremont, L., 2011. Evidence of herpesvirus (OsHV-1) resistance in juvenile Crassostrea gigas selected for high resistance to the summer mortality phenomenon. Aquaculture 317, 94-98.

Garcia, C., Thebault, A., Degremont, L., Arzul, I., Miossec, L., Robert, M., Chollet, B., Francois, C., Joly, J.-P., Ferrand, S., Kerdudou, N., Renault, T., 2011. Ostreid herpesvirus 1 detection and relationship with Crassostrea gigas spat mortality in France between 1998 and 2006. Veterinary Research 42, 73.

Glude, J.B., 1975. A summary report of Pacific coast oyster mortality investigations 19651972. Proceedings of the Third U.S.-Japan Meeting on Aquaculture, Tokyo, Japan. October 15-16,1974, pp. 1- 28.

Koganezawa, A., 1975. Present status of studies on the mass mortality of cultured oysters in Japan and its prevention. Proceedings of the Third U.S.-Japan Meeting on Aquaculture. Tokyo, Japan, October 15-16, 1974, pp. 29-34.

Littell, R.C., Stroup, W.W., Freund, R.J., 2002. SAS® for Linear Models, Fourth Edition ed. SAS Institute Inc., Cary, NC. 
Lynch, S.A., Carlsson, J., Reilly, A.O., Cotter, E., Culloty, S.C., 2012. A previously undescribed ostreid herpes virus 1 (OsHV-1) genotype detected in the pacific oyster, Crassostrea gigas, in Ireland. Parasitology 139, 1526-1532.

Majoy, A.P., Ford, S.E., Karney, R.C., Boettcher, K.J., 2007. Roseovarius crassostreae, the etiological agent of Juvenile Oyster Disease (now to be known as Roseovarius Oyster Disease) in Crassostrea virginica. Aquaculture 269, 71-83.

Malham, S.K., Cotter, E., O'Keeffe, S., Lynch, S., Culloty, S.C., King, J.W., Latchford, J.W., Beaumont, A.R., 2009. Summer mortality of the Pacific oyster, Crassostrea gigas, in the Irish Sea: The influence of temperature and nutrients on health and survival. Aquaculture 287, 128-138.

Martenot, C., Fourour, S., Oden, E., Jouaux, A., Travaille, E., Malas, J.P., Houssin, M., 2012. Detection of the OsHV-1 mu Var in the Pacific oyster Crassostrea gigas before 2008 in France and description of two new microvariants of the Ostreid Herpesvirus 1 (OsHV-1). Aquaculture 338, 293-296.

Maurer, D., Comps, M., His, E., 1986. Caractéristiques des mortalités estivales de l'huître Crassostrea gigas dans le bassin d'Arcachon. Haliotis 15, 309-317.

Oden E, Martenot C, Berthaux M, Travaillé E, Malas JP, Houssin M., 2011. Quantification of ostreid herpesvirus 1 (OsHV-1) in Crassostrea gigas by real-time PCR: determination of a viral load threshold to prevent summer mortalities. Aquaculture 317, 27-31.

Peeler, E.J., Allan Reese, R., Cheslett, D.L., Geoghegan, F., Power, A., Thrush, M.A., 2012. Investigation of mortality in Pacific oysters associated with Ostreid herpesvirus- $1 \mu$ Var in the Republic of Ireland in 2009. Preventive Veterinary Medicine 105, 136-143.

Pépin, J.F., Riou, A., Renault, T., 2008. Rapid and sensitive detection of ostreid herpesvirus 1 in oyster samples by real-time PCR. Journal of Virological Methods 149, 269-276.

Pernet, F., Barret, J., Le Gall, P., Corporeau, C., Dégremont, L., Lagarde, F., Pépin, J.F., Keck, N., 2012. Mass mortalities of Pacific oysters Crassostrea gigas reflect infectious diseases and vary with farming practices in the Mediterranean Thau lagoon, France. Aquaculture Environment Interactions 2, 215-237.

Renault, T., Le Deuff, R-M., Cochennec, N., Chollet, B., Maffart, P. 1995. Herpes-like viruses associated with high mortality levels in larvae and spat of Pacific oysters, Crassostrea gigas: a comparative study, the thermal effects on virus detection in hatchery-reared larvae, reproduction of the disease in axenic larvae. Veterinary Research Communications 26, 539-543.

Renault, T., Novoa, B., 2004. Viruses infecting bivalve molluscs. Aquatic Living Resources 17, 397-409.

Ropert, M., Mazurié, J., Bédier, E., Le Coz, F., Soletchnick, P., 2007. Evaluation of summer mortality risk factors in shellfish farming ecosystems. in: Samain, J.F., McCombie, H. (Eds.), Summer mortality of Pacific oyster Crassostrea gigas. The Morest Project. Quae Editions, Versailles, pp. 1-61.

Roque, A., Carrasco, N., Andree, K.B., Lacuesta, B., Elandaloussi, L., Gairin, I., Rodgers, C.J., Furones, M.D., 2012. First report of OsHV-1 microvar in Pacific oyster (Crassostrea gigas) cultured in Spain. Aquaculture 324, 303-306.

Sauvage, C., Pépin, J.F., Lapègue, S., Boudry, P., Renault, T., 2009. Ostreid herpes virus 1 infection in families of the Pacific oyster, Crassostrea gigas, during a summer mortality outbreak: Differences in viral DNA detection and quantification using realtime PCR. Virus Research 142, 181-187.

Sauvage, C., Boudry, P., de Koning, D.J., Haley, C.S., Heurtebise, S., Lapegue, S., 2010. QTL for resistance to summer mortality and OsHV-1 load in the Pacific oyster (Crassostrea gigas). Animal Genetics 41, 390-399.

Segarra, A., Pépin, J.F., Arzul, I., Morga, B., Faury, N., Renault, T., 2010. Detection and description of a particular Ostreid herpesvirus 1 genotype associated with massive mortality outbreaks of Pacific oysters, Crassostrea gigas, in France in 2008. Virus Research 153, 92-99.

Schikorski, D., Faury, N., Pepin, J.F., Saulnier, D., Tourbiez, D., Renault, T., 2011a. Experimental ostreid herpesvirus 1 infection of the Pacific oyster Crassostrea gigas: 
Kinetics of virus DNA detection by q-PCR in seawater and in oyster samples. Virus Research 155, 28-34.

Schikorski, D., Renault, T., Saulnier, D., Faury, N., Moreau, P., Pepin, J.-F., 2011b. Experimental infection of Pacific oyster Crassostrea gigas spat by ostreid herpesvirus 1: demonstration of oyster spat susceptibility. Veterinary Research 42, 27.

Takeuchi, T., Takemoto, Y., Matsubara, T., 1960. Haematological study of bacterial affected oysters. Rep. Hiroshima Prefect. Fish. Exp. Stn. 22(1), 1-7. Transl. U.S. Joint Publ. Res. Serv. For Transl. Program. Bur. Comm. Fish, Milford, Conn. (1965).

The Fisheries Research and Development Corporation, Ministry for Agriculture, Fisheries and Forestry, 2011. FINAL REPORT OsHV-1 $\mu$ Var. International workshop, Cairns, Queensland, Australia, pp. 101. 
Table 1: Key dates and mortality (\%) of the six cohorts

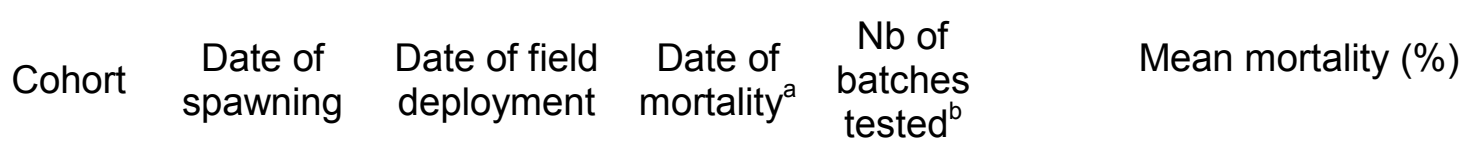

\begin{tabular}{|c|c|c|c|c|c|c|c|c|}
\hline & & & & & All $( \pm S D)^{b}$ & $R^{b}$ & $\mathrm{C}^{\mathrm{b}}$ & $S^{b}$ \\
\hline \multirow[t]{4}{*}{1} & $02 / 09$ & $07 / 09$ & WTW & $6 / 2 / 2 / 2$ & $75 \pm 20$ & 51 & 80 & 91 \\
\hline & & 08/09 & WTW* & $6 / 2 / 2 / 2$ & $58 \pm 39$ & 21 & 60 & 95 \\
\hline & & 09/09* & WTW* & $6 / 2 / 2 / 2$ & $51 \pm 44$ & 5 & 53 & 94 \\
\hline & & $10 / 09^{*}$ & $06 / 10^{*}$ & $6 / 2 / 2 / 2$ & $23 \pm 13$ & 8 & 33 & 29 \\
\hline \multirow[t]{7}{*}{2} & 08/09 & 03/10* & $06 / 10$ & $4 / 0 / 1 / 1$ & $83 \pm 12$ & NA & 93 & 92 \\
\hline & & $04 / 10^{*}$ & $06 / 10$ & $4 / 0 / 1 / 1$ & $81 \pm 10$ & NA & 86 & 93 \\
\hline & & $05 / 10^{*}$ & $06 / 10^{*}$ & $4 / 0 / 1 / 1$ & $85 \pm 9$ & NA & 91 & 94 \\
\hline & & $06 / 10^{*}$ & WTW* & $4 / 0 / 1 / 1$ & $86 \pm 14$ & NA & 96 & 96 \\
\hline & & $07 / 10^{*}$ & WTW & $4 / 0 / 1 / 1$ & $74 \pm 18$ & NA & 80 & 97 \\
\hline & & 08/10* & WTW & $4 / 0 / 1 / 1$ & $55 \pm 18$ & NA & 71 & 68 \\
\hline & & 09/10* & WTW & $4 / 0 / 1 / 1$ & $32 \pm 16$ & NA & 45 & 44 \\
\hline \multirow[t]{5}{*}{3} & $03 / 10$ & $06 / 10^{*}$ & WTW* & $6 / 2 / 2 / 2$ & $80 \pm 23$ & 54 & 92 & 95 \\
\hline & & $07 / 10^{*}$ & WTW & $6 / 2 / 2 / 2$ & $80 \pm 27$ & 49 & 95 & 97 \\
\hline & & 08/10* & WTW & $6 / 2 / 2 / 2$ & $73 \pm 32$ & 36 & 88 & 95 \\
\hline & & 09/10* & WTW & $6 / 2 / 2 / 2$ & $63 \pm 40$ & 17 & 77 & 94 \\
\hline & & 10/10* & $05 / 11$ & $6 / 2 / 2 / 2$ & $30 \pm 21$ & 7 & 41 & 43 \\
\hline \multirow[t]{3}{*}{4} & $07 / 10$ & $03 / 11$ & $05 / 11$ & $6 / 1 / 1 / 1$ & $72 \pm 31$ & 19 & 97 & 95 \\
\hline & & $04 / 11$ & $05 / 11$ & $6 / 1 / 1 / 1$ & $59 \pm 26$ & 17 & 86 & 80 \\
\hline & & 05/11 & $05 / 11$ & $6 / 1 / 1 / 1$ & $61 \pm 30$ & 10 & 87 & 95 \\
\hline \multirow[t]{7}{*}{5} & $08 / 10$ & $03 / 11$ & $05 / 11$ & $4 / 1 / 1 / 0$ & $67 \pm 30$ & 26 & 94 & NA \\
\hline & & $04 / 11$ & $05 / 11$ & $4 / 1 / 1 / 0$ & $70 \pm 27$ & 31 & 93 & NA \\
\hline & & 05/11 & $05 / 11^{*}$ & $4 / 1 / 1 / 0$ & $54 \pm 36$ & 6 & 88 & NA \\
\hline & & 06/11 & WTW & $4 / 1 / 1 / 0$ & $51 \pm 40$ & 9 & 91 & NA \\
\hline & & $07 / 11$ & WTW & $4 / 1 / 1 / 0$ & $58 \pm 27$ & 25 & 81 & NA \\
\hline & & $08 / 11$ & WTW & $4 / 1 / 1 / 0$ & $43 \pm 33$ & 7 & 81 & NA \\
\hline & & $09 / 11$ & $\begin{array}{l}\text { WTW+ } \\
05 / 12\end{array}$ & $4 / 1 / 1 / 0$ & $25 \pm 15$ & 12 & 43 & NA \\
\hline \multirow[t]{4}{*}{6} & $02 / 11$ & 06/11 & WTW & $6 / 2 / 2 / 2$ & $63 \pm 45$ & 16 & 80 & 93 \\
\hline & & $07 / 11$ & WTW & $6 / 2 / 2 / 2$ & $64 \pm 38$ & 22 & 83 & 88 \\
\hline & & 08/11 & WTW & $6 / 2 / 2 / 2$ & $62 \pm 37$ & 15 & 85 & 87 \\
\hline & & 09/11 & WTW & $6 / 2 / 2 / 2$ & $54 \pm 42$ & 7 & 78 & 78 \\
\hline
\end{tabular}

${ }^{a}$ WTW: within two weeks post-deployment.

${ }^{b}$ all batches (R, C, S and batches derivate from progeny from a cross made between $R$ and $\mathrm{C})$, and $\mathrm{R}, \mathrm{C}$ and $\mathrm{S}$ batches, respectively.

*: OsHV-1 disease diagnoses on live oysters at deployment or on moribund oysters during mortality outbreaks.

NA: not available 
Table 2: Pearson correlations $(r)$ and regression equations per genotype $\left({ }^{*} P<0.001\right)$

\section{Mortality}

\begin{tabular}{ccccc} 
& & $R$ & $C$ & $S$ \\
\hline$r$ & Individual weight & $-0.48^{*}$ & $-0.86^{*}$ & $-0.88^{*}$ \\
& Age & $-0.48^{*}$ & $-0.45^{*}$ & $-0.64^{*}$
\end{tabular}

Regression Individual weight $(g) \quad-0.418-0.061 X \quad 1.194-0.067 X \quad 1.859-0.108 X$ equation $^{\mathrm{a}}$

$$
\begin{array}{lll}
\text { Age (month) } \quad-0.114-0.089 X \quad 1.188-0.063 X & 2.481-0.168 X
\end{array}
$$

${ }^{a}$ mortality obtained from the regression equation is given on the probit scale, i.e. the inverse standard normal distribution of the probability

Table 3: Estimated mean mortality (\%) due to OsHV-1 from the regression equations, according to oyster size and genotype.

\begin{tabular}{|c|c|c|c|}
\hline Size $^{a}$ & $\mathrm{R}^{\mathrm{b}}$ & $\mathrm{C}^{b}$ & $\mathrm{~S}^{b}$ \\
\hline $0.16 \mathrm{~g}(10 \mathrm{~mm})$ & $33(26-42)$ & $88(84-91)$ & $96(95-98)$ \\
\hline $1 \mathrm{~g}(20 \mathrm{~mm})$ & $31(25-39)$ & $87(83-90)$ & $96(94-97)$ \\
\hline $5 \mathrm{~g}(35 \mathrm{~mm})$ & $24(19-28)$ & $80(76-84)$ & $90(88-93)$ \\
\hline $10 \mathrm{~g}(44 \mathrm{~mm})$ & $15(11-20)$ & $70(65-74)$ & $78(74-82)$ \\
\hline $15 \mathrm{~g}(52 \mathrm{~mm})$ & $9(5-15)$ & $57(51-64)$ & $59(53-66)$ \\
\hline $20 \mathrm{~g}(56 \mathrm{~mm})$ & $5(2-12)$ & $44(36-53)$ & $38(29-48)$ \\
\hline $30 \mathrm{~g}(65 \mathrm{~mm})$ & $1(0-7)$ & $20(12-33)$ & $8(4-17)$ \\
\hline
\end{tabular}

${ }^{a}$ size is given by the individual weight in $\mathrm{g}$ when an oyster is exposed to OsHV-1 for the first time. The corresponding length is given in parentheses.

${ }^{\mathrm{b}} 95 \%$ confidence limits are given in parentheses 


\section{Figures}

Fig. 1. Seawater temperature $\left({ }^{\circ} \mathrm{C}\right)$ from July 2009 to July 2012. The horizontal line represents the threshold of $16^{\circ} \mathrm{C}$ beyond which mortality was observed.

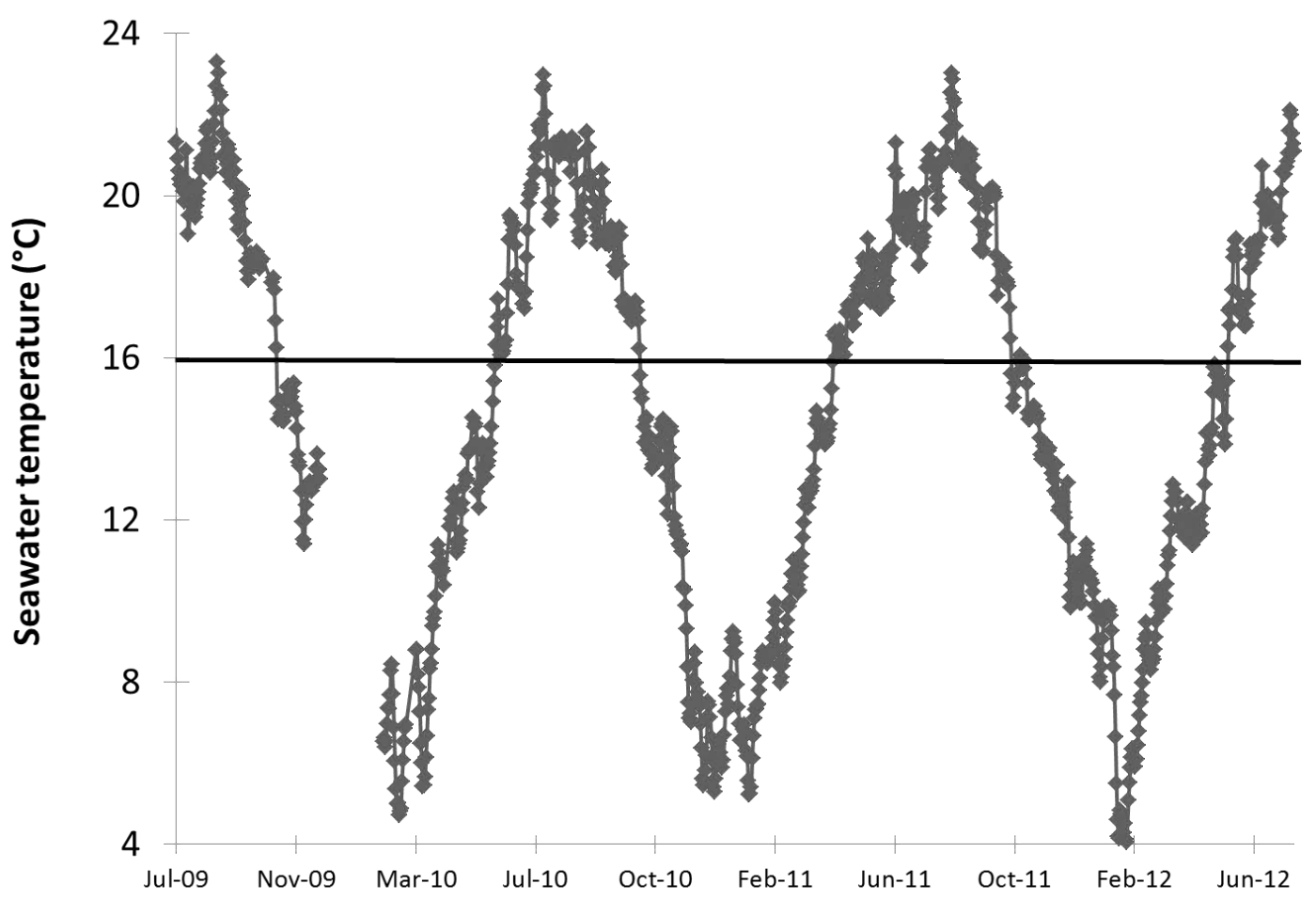


Fig. 2. Mean seawater temperature $\left({ }^{\circ} \mathrm{C}\right)$ over the two weeks post-deployment and the two weeks before mortality for each cohort and each deployment (a), mean individual weight at deployment and at mortality (b), and age at deployment and at mortality (b).
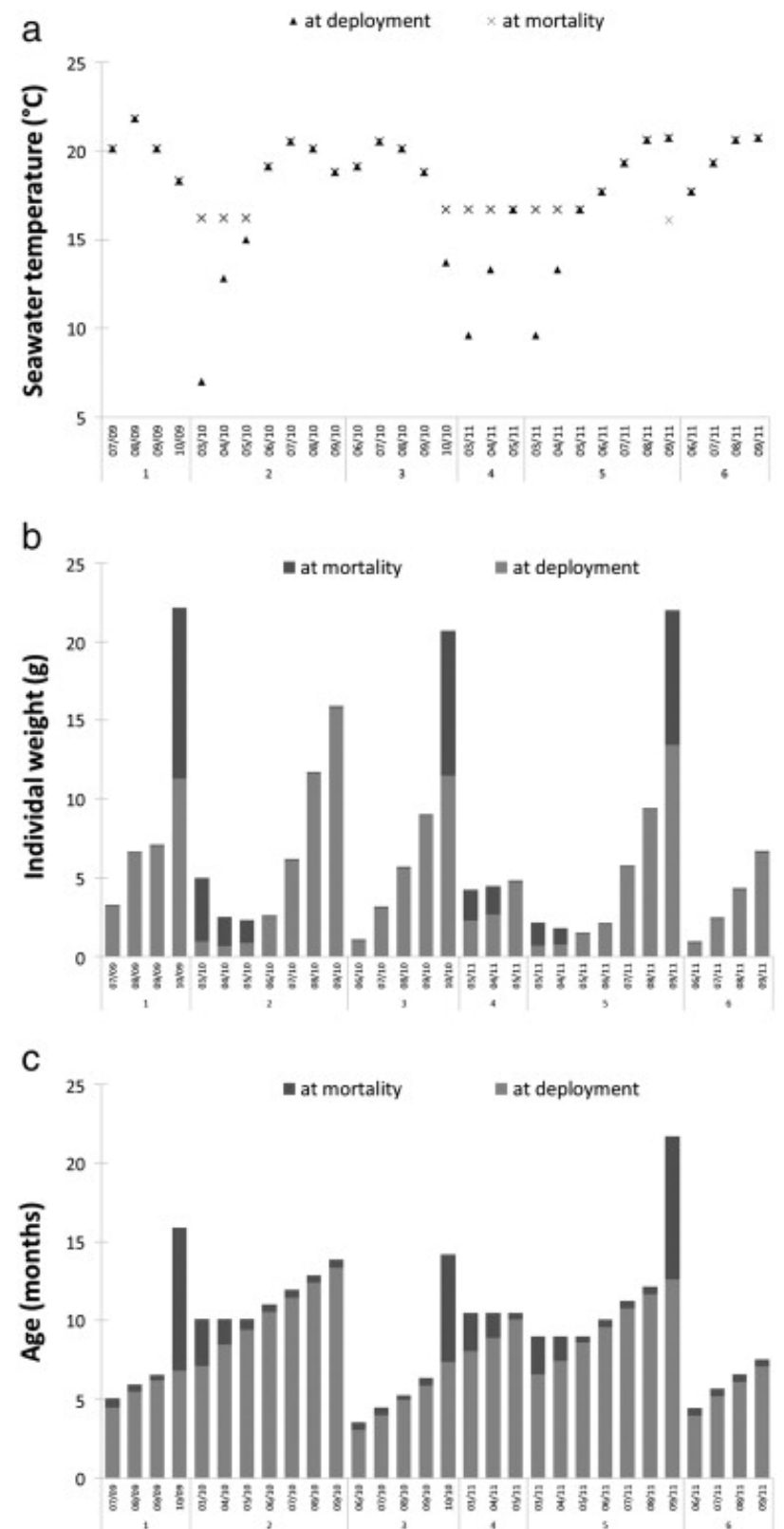
Fig. 3. Relation between age (a) or individual weight (b) and mortality due to OsHV-1 in the $\mathrm{R}, \mathrm{S}$ and $\mathrm{C}$ groups.
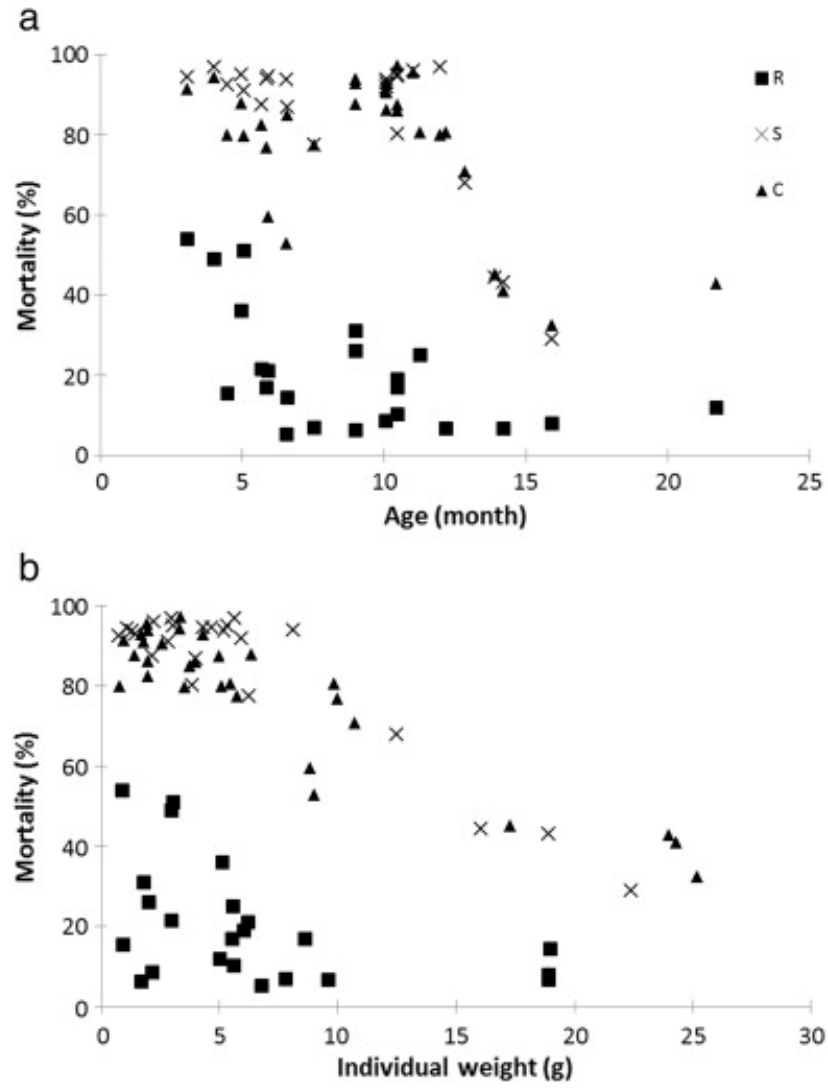